\title{
Study on the Research Value of Primary Orality
}

\author{
Guo Qijun \\ Jinan University, Guangzhou, Guangdong, China, 510610
}

\begin{abstract}
Keywords: primary orality; The Project for Protecting Language Resources of China; audio visual corpus; language resources
\end{abstract}

\begin{abstract}
Primary orality is defined as a spoken language acquired by the uneducated people through their mouths and ears. It contains a lot of language originals. It is also a "living fossil" for understanding traditional culture, customs, and social life in dialects and ethnic language areas. It is an endangered language resource that has so important research value that should be included in the top-level Chinese language resources protection project as soon as possible. In order to ensure the comprehension of the language collection and the sharing of language resources, it is necessary to build a primary audio visual corpus with comprehensive and standardized scene coverage on the base of field investigations.
\end{abstract}

Since the beginning of the $21^{\text {st }}$ century, education has gradually become universal. Electronic technology has developed rapidly, and urbanization has continued to advance. It has affected all aspects of national life, and major changes have taken place in language ecology. Among them, the illiterate language class is about to disappear with the popularization of education, and there will be fewer and fewer original spoken languages obtained in the context of oral communication. Shixuan $\mathrm{Xu}^{[1]}$ pointed out that "the preservation of the original ecological language appearance and cultural information as well as the preservation of the precious endangered language and cultural heritage are urgent goals and pursuits in today's era." The original ecological oral language is such an original ecological language. However, there is not enough understanding of this at present. Not only has there been little research on the spoken language used by illiterate people in the closed network, but it is only just the beginning of recording it. The original ecological spoken language should be raised to the same status as endangered languages.

\section{The Concept and Its Features of Primary Orality}

Primary orality was first seen in "primary orality culture."[2] "Primary orality culture" is a culture that does not know what words are. It is a culture that has not yet touched the text and is a culture that is not invaded by writing or printing. Obviously, on the one hand, primary orality culture emphasizes the characteristics of the user. That is, the user does not receive written education and does not understand the logical thinking of written language. On the other hand, primary orality culture itself has not been invaded by the text and is the original appearance of language ecology. Guangyi Feng ${ }^{[3]}$ pointed out that the native nature of language ecology is "the general natural appearance of the language ecosystem that is not affected by human factors." There is no contact 
between languages. Language is only a communication tool for tribes and ethnic groups. In today's world, the language of the illiterate ethnic group or tribe living in a closed network and the members of the network basically retains the natural appearance of language ecology. With reference to the above definition, we believe that primary orality is "an oral language learned by language educators in the context of oral communication." Primary orality has the following characteristics:

Firstly, the language host is not educated and does not understand the way of thinking in written language.

Secondly, language is learned naturally. From the analysis of language acquisition methods, language acquisition has the distinction between learning and acquisition. Learning language is a conscious participation process, and language acquisition is an unconscious natural acquisition in the language environment.

Thirdly, the acquisition and use of spoken language is limited to oral and ear communication.

Fourthly, the language use of language hosts is often limited to a certain space. Under the typical situation of primitive oral communication, communication only exists between members of the tribe. At most, there are a few tribes in the vicinity that are intermittently related. The smaller the communication circle, the more concise the communication behavior will become. ${ }^{[4]}$

In other words, primary orality is the everyday speech used by illiterate people in closed communication networks.

\section{Research value of Primary orality}

\subsection{Primary orality is a precious language heritage. It is an initial stage in the development of} human languages and reflects the early appearance of language and the laws of communication

"From the perspective of the origin of language and the way of language communication, the native ecology of language can only be spoken form."[3] Oral communication is the initial communication method of human beings, and it is also the most basic communication method. Written and electronic communication of language is based on oral communication. The language communication in the background of oral communication has the characteristics of immediacy, information protrusion, clarity of speech, and brevity of sentence. The written and electronic communication of language is influenced by the medium of communication. The subject of communication has more time to think. Therefore, the sentence is longer and the discourse structure is logical.

After oral communication transits to written communication and electronic communication, the changes in the language subject are at least manifested in: firstly, the language host is changing from "I don't know what the text is" to receiving text education; Secondly, the scope of activities of the language host has gradually expanded, and the scope of language use has gradually exceeded the "acquaintance society" formed by blood and geographical relations, and has expanded to different speech communities and speech societies. Transiting from oral communication to written communication and electronic communication, it is not only the history of media renewal, but also the history of language communication. Influenced by the medium of communication, the speed of language transmission at each stage, the object of transmission, the results of transmission, the mutual contact and competition between languages will show some differences, and the language life of the language host will also follow the changes. Primary orality reflecting the early language appearance of mankind is a linguistic and cultural heritage, and also helps us to understand the language appearance under the background of oral communication and the law of language transmission. 
2.2 Native oral language is also a valuable cultural heritage that records the linguistic and cultural ecology of a region, network, and group

The language of a place often records the state of local cultural life. The remnants of the language at the bottom often show the local people's traditional culture, social psychology, thinking style, and life style. The changes of language use reflect the changes of local social and cultural customs. On the one hand, primary orality retains the most "language bottom", which is a "living fossil" that understands traditional culture, customs, and social life in dialect areas and ethnic areas. On the other hand, from the development of primary orality and the spoken language of the educated, the development history of the local language and the language life of the local people can be observed, which is of great significance for the establishment of a local language and culture museum.

"Language is a symbolic system constructed through society and culture"[5] The communicative interaction of speech is also the process of forming and constructing social networks. People who are in frequent contact with each other form a social network based on the same identity, class, occupation, age, personal intention, communicative will, as well as social and cultural regulations. Many people's social network synthesis constitutes a certain area of social structure, such as blood network, geographical network, industry network and so on. Social networks are divided into closed networks and open networks. Closed networks have a high degree of cohesion. The network members have the same social background and cultural regulations, etc. Besides, the network members have a high degree of recognition. Based on the same social background and cultural regulations, the language interaction between members within the network forms the default behavior norm model. Based on shared knowledge, communication between members within the network becomes casual, intimate, and the code becomes concise. Primary orality is mostly used in closed acquaintance society. Its language characteristics represent the language communication mode of closed network. Recording and studying primary orality is the best material to understand the member language appearance and communication mode in closed network.

Each language is a unique reflection of human understanding and experience of the world, and of the values and perceptions of its users. Laria. A.R's survey ${ }^{[6]}$ of illiterate and semi-illiterate people found that illiterate people identify geometric figures by directly naming them with objects, not circles, squares, etc. Illiteracy classification of vocabulary is a situational classification rather than an abstract category classification. Illiteracy can not carry out deductive reasoning thinking, such as three-segment theory. Illiteracy can not define specific words and things. Primary orality reflects the language cognition and thinking habits of illiterate people.

\subsection{Primary orality is an indispensable resource for the study of language education and language cognition}

Language education is a goal that mankind has long pursued. The connotation of "language" has different interpretations. Leaving aside the meaning of "literature and culture" of "text", "language" means spoken language, while "text" means written language, and "language education" is the process of mastering written language. In other words, those who have received language education have two sets of spoken and written language codes in the library; For those who have not received language education, there is only the spoken language code in the corpus. The difference between spoken language and written language is relatively clear. For example, spoken language is short and does not emphasize the logical relationship. It also has a large amount of redundant information. In contrast, written language is long and the logic is rigorous. In addition, its expression is concise. However, the impact of language education on spoken language is still not clear. The current language education promotes the changes in spoken language. These questions need to be compared 
between native and non-primary orality to solve them.

The influence of language culture and education on cognition has always been an important research field in pedagogy, psychology, linguistics and neuro-cognitive science. As a special group, illiteracy's cognitive characteristics provide the opportunities for school education to study the cognitive impact. ${ }^{[7]}$ These studies focus on speech processing, semantic processing, and word processing. Numerous studies have shown that the cognitive aging of illiteracy is earlier than that of Yufei. So are there any differences in language performance between illiterate and non-illiterate people in cognitive aging? If so, what are the differences? Can language education be used to slow cognitive aging? The answer to these questions also depends on the research results of primary orality.

\section{Conclusion}

According to some relevant data, 85 million people were illiterate in China in 2005, and China's illiteracy rate fell from 80 percent at the beginning of the founding of People's Republic to 8.72 percent in 2005, of which 4.8 percent were the young and the middle-aged. Under the conditions of contemporary history, primary orality has become an endangered language resource. Through recording and retaining primary orality, we must fully realize the value of language and cultural heritage as well as resource value contained in primary orality. Recognizing the urgency, importance and remediation of native oral records and preservation, it should be recorded in the language protection project as soon as possible. Recording and retaining Primary orality can also enrich the content of language and cultural collections.

\section{References}

[1] Xu shixuan. The course and prospect of endangered language research in China.Journal of Northwest Minzu University(Philosophy and Social Science),2015(01):83-90.

[2] Walter J.Ong. Orality and Literacy: The Technologizing of the Word, Translated by He daokuan, Peking University Press, 2008:6+30-31

[3] Feng guangyi. A Introduction of Language Ecology. People's Publishing House, 2013:54+231-234.

[4] Edward Sapir. Edward Sapir in Language, Culture, and Personality, university of California Press, 1949:101-103.

[5] John J. Gumperz. Discourse Strategies Cambridge University Press, 1982:170-175.

[6] Luria.A.R. trans by martin lopez-morillas \& lynn solotaroff. cognitive development: its culture and social foundation, Harvard university press, 1976:32-34.

[7] Cao Xiaohua. ect. The Behavior and Brain Function of Word Processing in Illiterate Subjects, Advances in Psychological Science,2009,17(05):917-922.

Author information:

Guo Qijun(1982 --), male, born in Qin an district of Gansu province, Ph.D. student from the College of Chinese Language and Culture of Jinan Universtiy.

Contact address: No. 377, Shou gou ling Road, Tianhe District, Guangzhou, China.

Postal code: 510610

Telephone: 18826237281

Mailbox: Huihong8221@163.com 